\title{
R.U.S.I. Gold Medal Prize Essay
}

\section{Lieutenant Lionel H. Hordern}

To cite this article: Lieutenant Lionel H. Hordern (1902) R.U.S.I. Gold Medal Prize Essay, Royal United Services Institution. Journal, 46:290, 437-458, DOI: 10.1080/03071840209418996

To link to this article: http://dx.doi.org/10.1080/03071840209418996

$$
\text { 曲 Published online: } 11 \text { Sep } 2009 .
$$

Submit your article to this journal

Lll Article views: 8

Q View related articles $\longleftarrow$ 


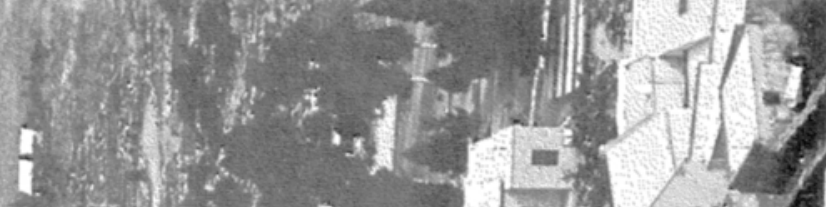

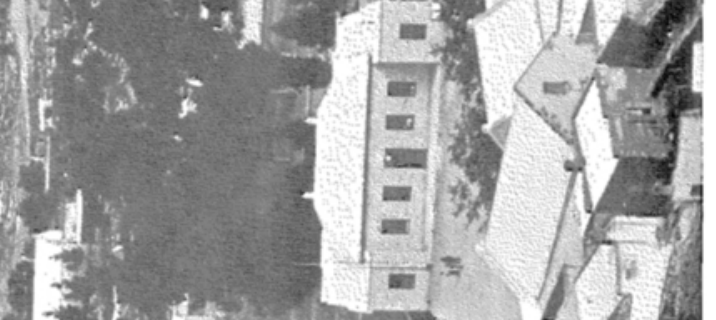

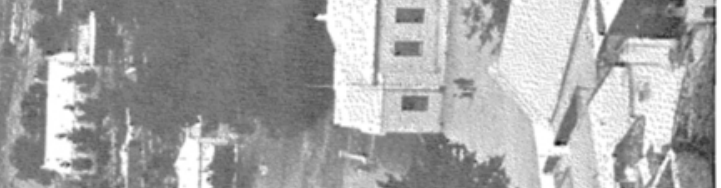

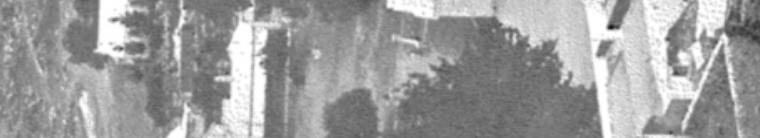
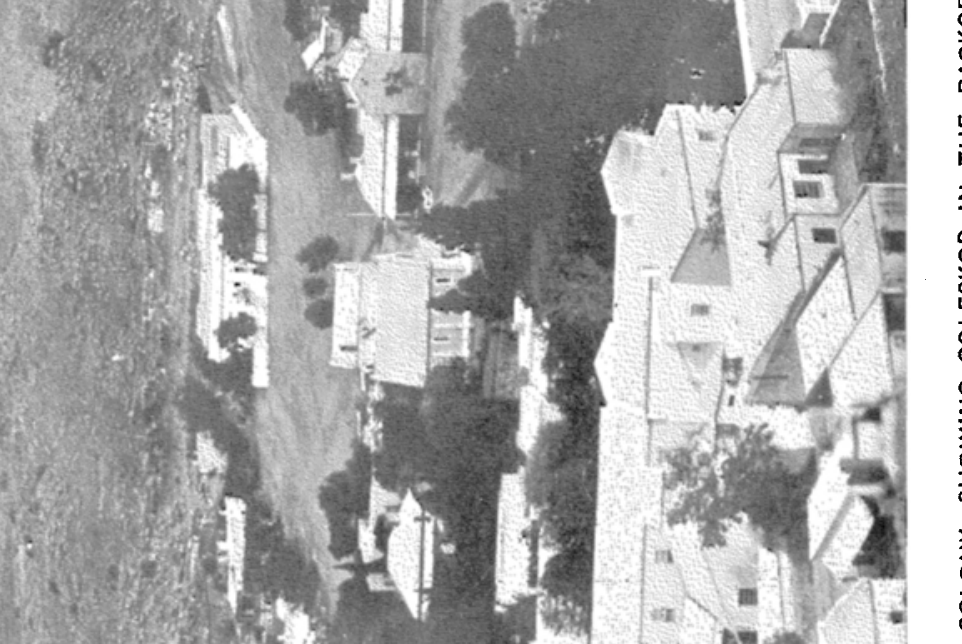

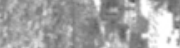

if, 0

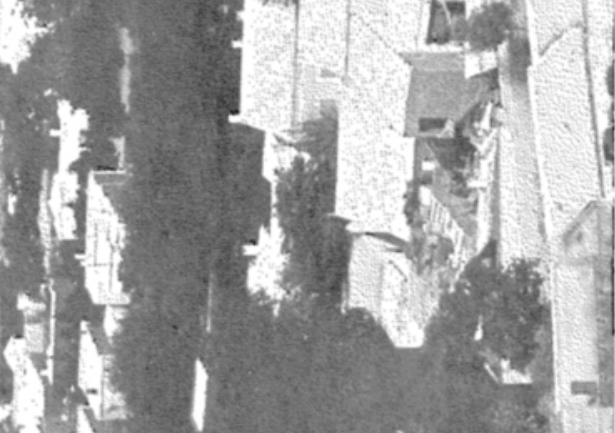

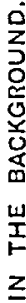

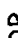

홈

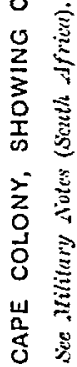

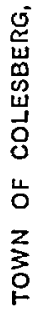

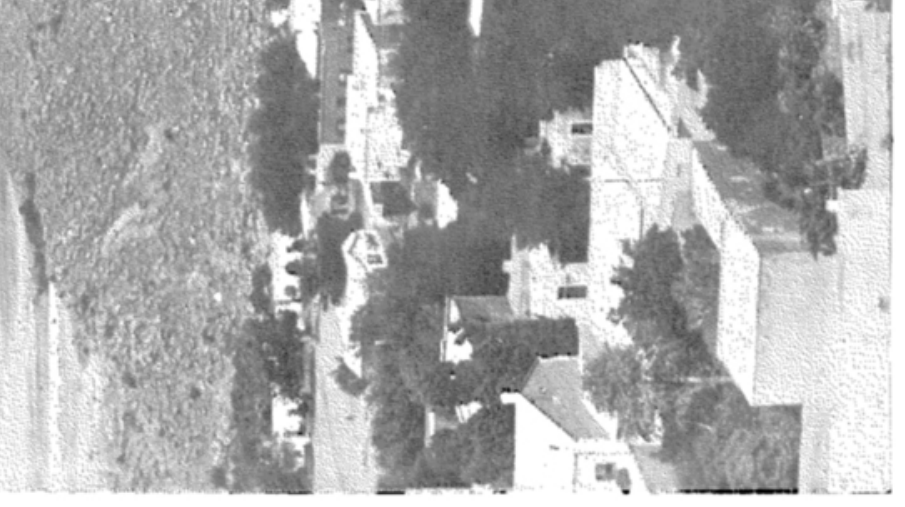

呫 


\section{THE JOURNAL}

aI TE

\section{ROYAL UNITED SERVICE INSTITUTION.}

VoL. XLVI. APRIL, 1902. No. 290.

[Authors alone are responsible for the contents of their respective Papirs.]

-R.U.S.I. GOLD MEDAL PRIZE ESSAY.

Subject :-

"WHAT SHOULD BE THE DISPOSITION OF THE MATERIEL. AND PERSONNEL OF THE BRITISH NAVY IN TIMI: OF PEACE, AND HOW CAN THE PIEACE STRENGTH BE MOST RAPIDLY EXPANDED TO WAR STRENGTH ?"

B. Licutenant LIONEL H. HORDERN, R.N. (Retired).

"Maris Imperium Salus Imperii."

THE answer to the first part of the subject set for discussion, "What should be the disposition of the materiel and personml of the 3ritish Navy in time of Peace," must depend upon the best distribution of the Navy; for war. And before we can answer the second part, "How cin the Peace Strength be most rapidly expanded to War Strength?" we must enquire how much of the war strength we can afford to keep on a peace footing. If we may. judge from past experience, war when it does come will almost certainly be unexpected, and, even if there is warning, it will be impossible to mobilise beforehand without precipitating the very evil we wish to aroid. The peace distribution must, therefore, depend entirely on war requirements.

It must at once be conceded that the actual position of each ship, whether battle ship; cruiscr, or auxiliary, mușt be decided by the Admiralty. The Government alone are in a position to know the chances and risks of a collision with other Powers. The Admiralty alone know with any accuracy the strength and state of preparedness of those Power.

vol. Xivi. 
It is for them therefore to decide with the fill knowledge they possess what is the strategy to be adopted in the event of war, and consequently the distribution of the Navy during peace. The building programmes of the various naval Powers show that they are not content to allow us to have the undisputed command of the sea, and one of them, Germany, has definitely said so. The desire for sea power on the part of other nations is a factor to be reckoned with, for with the exception of the United States and Japan they have no need of this for purposes of defence. Without any very clear reasoning and apparently almost as an instinct of self-preservation, it is taken as an axiom that we must be strong enough at sea to meet succesifully the two next strongest European Powers combined. But that this ilea may have to be abandoned seems highly probable, when the rapid growth of the German and other Navies is taken into consideration. If we compare the strength of the British Navy with that of the Navies of other nations, we shall see at once that the task before the Admiralty now is not a light one.

In 1889, an official commission of three admirals considered that the standard of comparative strength of the British and a hostile force should be five battle-ships to three. For cach battle-ship it is generally considcred there should be one scout, while the writer of the Prize Essay in 1897, on the Protection of Commerce, estimated that this duty would require approximately 160 cruisers and torpedo-gunboats, besides about 90 each destroyers and topedo-boats. It is doubiful if the duties assigned to destroyers in that essay could in many cases be carried out by such craft, and it is probable that another 20 cruisers would have to added on this account, to enable his views to be carried out.

The Admiralty Return for 1901 gives the battle-ships of the two next strongest European lowers, France and Russia, as 13 . On the foregoing basis we should therefore require $i 2$ battle-ships and 250 cruisers and torpedo-ressels. Towards this ideal fleet the Admiralty list provides us with 50 battle-ships (including 4 broadside ships over 30 years old, and 7 others from 20 to 30 years old, armed with muzzle-loading guns), and 158 cruisers and torpedo-ressels.

No later principle than the above being public property, and this being clearly quite impossible to comply with, we. must endeavour to station our fleet so as to give it the best chance of success with the force at our disposial.

In attempting a practical distribution of the British lilect, it is assumed that the flcets at the disposal of the various Porvers are those sprecified as "built" in the Admiralty Return of 28 th MIarch, 1901. The stations of foreign ships are in some cases ascertainable, in others no information can be found in the Press. A situation approaching the actual fits is therefore all that can be attempted, and in the tables 
giving a suggested distribution for the British Flect, in accordance with the principles advanced, it must be taken that this is entirely dependent on the distribution of the opposing fleets being as assumed. However incorrect the assumed positions may be, the arguments will not be affected.

\section{DUtY OF THE NAYY IN WAR.}

Before we can lay down any general principles on the subject before us, we must in the first place decide what are the duties'of the Navy in war. - The general expression to denote these duties is that we must have the "command of the sea.". Our colonies and possessions, which lie in every part of the world, are an integral part of the Empire. In these respects we differ immensely from any other nation. The colonial possessions of other Powers are merely undeveloped properties-they can be parted with or exchanged without any real damage to their owners. The ideals are utterly difterent in the two cases. With us a colony is a part of the Empire in a more or less developed state. With other nations it is to a very large extent merely a district which can be traded with on the best terms for its owners, a market for surplus manufactures. The inhabitants, apart from officials, are the natives of the country and are not a part of the nation itself.

With us, the mercantile marine is the only means of communication between the various parts of the Empire. The trade routcs are our railways and military roads. If in war the ships of any other nation are compelled to remain in their own ports, that nation would suffer scarcely at all, she may lose some or all of her oversea possessions without being very much affected. But if our ships are driven from the seas, the Empire must fall to pieces for want of communication between. its parts. For the British Empire, therefore, the "command of the sea" is not merely an expression, it is an absolute necessity. Unless it is ours without question, the Empire is dismembered. The sea is really as much a part of the Empire as any of the lands claiming to be so, and the protection of this part of the Empire must fall on the Navy. We see then that the boundaries we have to defend must be wide enough to include the trade routes and cannot be confined to our own coast lines, or, as it has been put, our frontier is the enemy's coast.

This implies rapid, energetic, and offensive strategy for the flects, and in order that they may, be able to take full advantage of the nearest ports of the Empire to their theatre of action there must be one or more naval bases in each of the great divisions of the sea. These naval bases, whether primary or secondary, must be strongly held, for on them the fleets depend for coal, ammunition, supplies, and repairs, but at present no very clear line is drawn as to where nival responsibility ceases and that of the Army begins in their defence. 
In a war in which we had to put forth all our energies, the commend of the sea must first be assured to us; until it is so assured, the Army must act on the defensive. We cannot think of attacking the enemy on his own soil unless the seas are clear and our communications secure.

To attain this, the Navy must be free and the whole of its fighting force must be available. If this force is frittered away in defending harbours and coasts, the $\mathrm{Navy}$ will be hampered and tied, and cannot act in the best manner. The local defence of our coasts and ports, even of our great naval ports and coaling stations, should therefore not in any way depend on the Nary. Other nations, to whom the command of the sea is not a vital question, can leave the defence of these bases primarily to their Navies, but for us to do so would be to reduce our fleets to impotence. If the Navy were strong enough at sea the coasts would not require fortifying except against raiders, and it should be clearly laid down that the Navy is not responsible in any way, for the defence even of its own ports and coaling stations. The "three-mile limit" might well be taken as the dividing line between the naval and military responsibility for defence, and it should be definitely stated that no man or vessel under the Admiralty could be counted upon to assist in $\mathrm{tr}$ a defence of any port they might happen to be in.

The risks incurred by the fleet in leaving the defence of the naval ports to soldiers are doubtless great. The latter cannot be expected to recognise by her appearance whether an approaching ship is friend or foc, and instances have constantly occurred at manœuvres of friendly ships having been theoretically sunk by the forts which should have protected them. But the same thing has occurred in the Nay itself with. regard to torpedo-boats, and it would be better to face this risk rather than to lock up seamen in harbour or to use any part of the fleet as a stationary defence.

Such a dividing line would at once make clear to everyone what the duties of the flest really ari, and would remove such mistaken ideas as that the Chánnel and Reserve Squadrons are for the defence of the Channel and home waters respectively. These ideas, which constantly appear in the Press, are stated as if the function of these squadrons was literally to repel invasion, whereas their duties are really to prevent the enemy entertaining such an idea. It woulc also prevent such proposals as those which the Secretary of State for. War lately brought forward being even thought of. To-turn over the defence of the coaling stations to the Navy shows a misconception of the latter's duties which must lead to confusion in war. The above will answer the arguments of those who consider that the defence of the coasts should be left to the Admiralty. To form a third force for this purpose, as has been sometimes suggested, would be merely to add to the present confusion. 
It will be taken then that the functions of the Navy in war are two, and two only: (1) The destruction or containing of the enemy's flect; and, (2) The protection of commerce; and that it is no part of their duty to assist the Army either in the defence of the coasts or in attack, at least in the earlier slages of a war-which is all that we are concerned with here.

\section{Pronable Opponents.}

We must now proceed to enquire as to whom we must be prepared to fight. In the first place, it is evident that we have not a sufficiont force at our disposal to meet everyone at the same time, and that such a contingency is very remote. It is unlikely that the United States would join with all the Furopean Puwers against us, and it can hardly be to the interest of Japan, the only other extra-European Power with a modern fleet of any strength, to do so either. It may, therefore, be taken that, wc need not weaken ourselves by detaching battle-ships to these stations under normal conditions, unless some of the European Powers should have done so. Again, we may ignore the smaller European Powers whose fleets are more suitable for the purpose of defence. 'They are unlikely to be found all on the same side, and even if they were our, margin of strength should be sufficient to prevent them turning the scale against us. There remain then the great Furopean Powers, who are divided into the Dual Alliance (France and Russia) and the Triple Alliance (Germany, Austria, and Italy). If these two groups were to join against us, we should be over-matched, and could hardly by ourselves retain the command of the sea. What chance there is of such a combination is a question for statesmen, and, as ro Government has thought it worth while to provide against it, we may assume either that they consider the chance a very remote one, or that they feel assured we shall receive help in such an eventuality from extraEuropean Powers. We will therefore dismiss this idea as one with which we need not concin ourselves, but it may be remarked that alliances are not for all time, and that a fresh grouping of the Powers may take place more quickly than we ean build battle-ships or train crews to man them. Whether it is wise to stake the existence of the Empire on such arguments may well be doubted, but we are here concerned onls with the Navy as it exists, and we must, therefore, take it that, in the event of war, we shall have to meet either the Dual or the Triple Alliance, the other maintaining neutrality.

Stratrgicat. Consinerations.

The sea power of both these alliances is formidable, but strategically the situation is much the same in either caise. A strong force in the 
Mediterranean, a somewhat weaker force in the Channel, North Sea, or Baltic. The disposition of our ships to cope with one group would therefore almost serve for the other; but that the Dual Alliance having war-ships on other stations, notably in the East, we must detach certain ships of somewhat greater power to the same quarter of the globe to deal with them.

Strategically, we occupy the interior position between the divisions of the enemy's fleet. 'Ihese divisions may of course act independently, but it is more probable they will try to combine. This involves one or more divisions passing through the Straits of Gibraltar, and it is doubtless this which causes it to be regarded as the first move on our part to concentrate the Mediterranean and Channel Squadrons there. This proceeding involves a certain risk, because if the enemy's northern divisions, instead of procecding at once to Gibraltar, were to concentrate in the Channel, we should have to oppose them there only a fleet made up of ships which were not of the first class, and which had been hastily. brought together. Our'defeat there would leave the Channel in a dangerousily open state. On the other hand, it is imperative that the divisions of the enemy's fleet should not be allowed to combine before our separate squadrons, watching each division, 'can also join hands, and also that our squadrons should each be strong enough to defeat the divisions they are opposed to. We, thereforc, require a squadron in the Mediterranean to oppose either the French and Russians, or the Italians and Austrians; another in or near the Channel to oppose the. French Northern Squadron or the German Fleet, and, in a war with the Dual Alliance, a third squadron in the North Sea to oppose the Russian Baltic Squadron. The naval power of the Dual Alliance being the stronger, it will be sufficient to consider them principally; a very slight alteration, if any, would be required to the dispositions made for the purpose of meeting France and Russia to adapt them to meet the Triple Alliance, and we may, therefore, station our ships with a view to a war with France and Russia.

\section{Distrinution of Duties.}

At present the responsibility for keeping open the trade routes in the respective stations is considered a part of the duties of the admirals in command. This system allots to each admiral a certain number of cruisers for the duty both of scouting for his battle-ships and protecting the commerce on his station, and it is left to him to apportion them as he thinks best. If he has a sufficient supply of cruisers for both purposes, all no doubt will be well ; but if, as history teaches us to expect, and as most naval officers believe, we shall be short of cruisers when war comes, then one duty or the other will suffer, either the battle-ships will 
be short of scouts or the trade routes will be insuficiently protected. Which is the more likely to happen we may, gather from the last manourres, where the attack on commerce was entrusted to torpedo-boat destroyers and the defence not attempted. This duty of protecting commerce cannot be neglected. The mare outbreak of war will cause the price of breat to rise befure even a single ship is captured. A few ships are certain, even unter the best arrangements, to be lost at first; and unless confidence can be quickly restored, the results may easily be serious. A large part of the population of London and other big towns live from hand to mouth with very lit!le, if any, margin for contingencies. A rise in prices must affect them enormously, and disturbances are certain to oscur if they have any idea that this rise is likely to be maintained. If this duty of protecting commerce is left to several different heads, as it present, "different systems will be adopted, which, though they may each be good for one particular station, will not necessarily be the best for the object treated as a whole, and there will undubtedly be overlapping, which the state of the Navy cannot afford.

Again, it will be-necessary in some cases to follow a commercedestroyer from o:ne station to another, and if no special ship is definitely allotted for this purpose an adiniral in command of a station may well hesitate to send one of his strongest cruis:rs off his station when by so doing he would be weakening his fighting squadron. He would naturally feel that he had don: enough in driving the enciny off the trude route he was responsible for, and that it was the duty of the adjoining station to take up the hunt. The duties of scou's and commerce-protectors are entirely distinct and should be kept so. 'The former are only requirel to capture other ships for the sake of obtaining information for their own fleet or of preventing information reaching the enemy. Their objects are the same as those of cavalry screens and patrols. Commerceprotectors, on the other hand, have a different mission, and should not be require 1 to deviate from it to carry information to the fleet. They must attack their opponents an I disable them at-whatever cost to themselves. 'Their rôle is that of a mobile column hunting down guerilla bands.

From these arguments it would seem that it would be of advantage if the co:nminder-in-chief on the stations where we have battle fleets were relieved of this duty of pretecling commerce, and if it were attended to by a separate head at the Admiralty. "The admirals in command of battle flect; must, of course provide for their own communications with their base, but their duties in this line should end there, and it should be the duty of the admiral in charge of trade routes to see that the supplies are safely taken to the base. This system would give a freer hand to the admirals in command of fleets watching the enemy's fighting squadrons, and they would not be expected to 
make their cruisers do double duty. Both scouting and protecting commerce are of the greatest importance, but the training for, and the requirements of, each are different. $B y^{*}$ separating the ships and commands in this way, both can be fully attended to.

\section{Distrinution of the lifeet for War.}

From the above it will be seen that we require three permanent battle squadrons, while at present we also have a fourth, possibly temporary, squadron in Chin 1 . Wh should next enquire what the object of these squadrons should be and what should be their strength. In war the stronger Power may either blockade the enemy's fleet, or may contain it by stationing its flect in a position where the enemy must pass so as to ensure an action, shoald the enemy come out of harbour. For the former purrose it has been laid down that the number of blockading ships mist be at least one-third more than those of the enemy, so as to allow for a circulation of ships to the base for coaling, etc. If the base is a considerable distance off, as Mialta or Gibraltar from Toulon, an cven larger proportion may be required. Now a glance at the lists of ships in the tables attached will at once show that we have not got the large number of ships required for this purpose, and that, therefore, the slose blockade of the o'd wars would not be possible for us. Moreover, the conditions are changed, and it is doubtful if such tactics would be the best. So much depends on coal, that a fleet with full coal supply, chased by one with bunkers in various stages of depletion would have its chances of escape enormous!y increased. If, therefore, a base, whether permanent or temporary, can be found for the containing fleet, in such a position as to ensure catching the enemy should he leave harbour, this is cleariy the system which will have to be adopted. In our case there is no choice, we are compelled to take this course and so appotion our battle-ships between the various squadrons as to leave us in each with a slight preponderance in our favour.

A possible course of action for the enemy's flect has been suggested above, but it may be that knowing our difficulty in enforcing a blockade, and the distances of our bases in the Mediterranean from Toulon, they. may clect to keep their battle-ships in harbour at first, sending the majority of their cruisers to make raids on our commerce in the hops of drawing off our scouts, and then of being able to slip past our battle-ships. In the Channel this couse might be even more advantageous to them, for our squadron there would either have to keep at sea, depleting their coal bunkers, or to lie at Plymouth with the chance of being unable to catch the French Northern Squadron before they could get to Gibraltar. What ever ccurse they may adopt, we must provide that the exigencies of commerce defence do not require us to withdraw our scouts. 
Having decided upon the main lines of our policy in stationing the battle squadrons, we must apply the same principles to our squadrons in other parts of the world. To do otherwise would be to act without a general idea and to incur the risk of dividing our forces. In whatever part of the world then the Dual Alliance have men-of-war, we must have others of the same type in greater force. 'Further, should France and Russia detach part of their forces from their European stations to others, we must do the same, taking them as far as possible from corresponding stations. The Chinese affair is an example.

The second group of stations contains those on which the Dual Alliance have a few ships. On these stations, North America and the East Indies, the French have a few cruisers in commission, and we must, therefore, have others either in slightly greater number or of greater power. These ships must be kept in commission for the same reason, as given above, for battle squadrons. But on these stations, as well as on those in the third group, Australia, South Africa, South America, and the Pacific, where there are no French or Russian ships stationed, we shall require some ships for commerce defence. In the second group the Dual Alliance have bases and coaling stations, but in the third they have very few places where their ships could coal, and they would, therefore, be the less likely to attack our commerce there. Probably the few ships we are obliged to keep in commission for police duties on both these groups would be sufficient for this purpose, but it would be advisable that there should be a few of a better class than the sloops and gun-boats at present stationed there. 'The ships on these stations may have to steam long distances or even to change their stations in chase of an enemy's cruiser, and, though we have more coaling stations than the Dual Alliance, a ship chasing must burn more coal than the ship chased, as she has to find her. It is unlikely that the enemy would weaken themselves by sending many ships to attack our commerce in these parts of the world, though those they do send will want some finding.

As to the class of ship to be apportioned to these different duties, we have first clearly to distribute our battle-ships so as to give us some. advantage in each feet over the battle-ships of the enemy. Ship for ship, ours are stronger and more homogeneous than theirs. Of these points we must take full advantage, for our superiority in numbers is very small. This having been done, we should allot to each battle-ship a scout. Of the enemy's battle fleet there then remains his const-defence ships and armoured cruisers. We should meet both these, ship for ship, with our own armoured cruisers.

We are, it will be seen from the tables, very short of this class of ship, t'io ugh there would appear to be two classes of the enemy's ships with which they would have to deal, and if we are to apportion one of 
ours to each of these we shall at present have to use the larger protected cruisers to perfor.n the duties of armoured cruisers. It is quite possible, as suggested above, that the eneiny may send off his armsured cruisers to destroy our commerce, in which case we must send others after them. The watching of the enemy's fleet in harb our will have to be parformed by our scouts, and they must have some heavier ships to fall back upon, or even in the absence of his armoured cruisers our scouts may be driven off at the critical moment by his coast-defence ships. With both fleets at sea, our armoured cruisers, which are really light battle-ships, would probably form a separate division, and may even be detached on separate service. For this purpose they should be provided with scouts, but we are too short of these to be able to allut any to them.

Auxiliary ships, such as hospital, coal, and store ships can hardly be said to exist in our Navy at present, but no doubt they will be provided by degrecs. At present they would have to be taken up from the mer antile marine, and, so far as disciplined crews are required, they could be furnished by the Naval Reserve.

There remain now the destruyers and torpedo-boats. How far it will eventually be found advisable to keep destroyers with the fleet is perhaps uncertain. On the one han:l, they may be very useful in warding off attacks on a blockading fleet, or in carrying messages; but on the other hand, their value for scouting purposes is almost nil, owing to their small angle of vision, and they would be a positive hinderance to a fleet at sea searching for an enemy. Probably their best station will be at the base port of the station, ready to accompany the flect, to join it when required, or to act independently. For the protection of commerce they conld be employed where this is threatened by torpedoboats.

The duties of torpedo-boats will be taken here as to attuk the enemy whencver a farourable opp ortunity occurs near the coast to which they are attached. Acting generally in groups under the command of a smart officer, they will have general directions as to the part of the coast they are to go to and the ships they may have to altack, leaving all details both as to when and how to attack to the officer in command. Some of these boats will be alwajs in commission with a view to training their crews and gaining knowledge of the coasts they are to be employed on, but they, as well as the destroyers, will be under the Admiralty, and so will not form part of the defence of any port or part of the const.

Comperce Defexce.

In accordance with the irguments advanced above, it will be taken here that on stations where we have battle fleets there will be a separate organisation for the protection of commerce, in the shape of a sp.cial body of cruisers other vessels, under a rear-admiral or commodore, 
these oficers, as well as those commanding the stations in groups 2 and 3 , being directly under a senior admiral in England, who will be in charge of the defence of commerce throughout the world. There is already in commission a Cruiser Squadron in the Channel under a rear-admiral, a similar squadron might be formed in the Nediterranean, and smaller squadrons in the North Sea and China under commodores-the class of ship being those suited to the station. These cruiser squadrons would be independent of the commanders-in-chief on the stations in war-time and might also be so in peice as in the present Cruiser Squadron in the Channel. ${ }^{1}$ If that were thought inadvisable in foreign stations they might form part of his command, with the understanding that they were as far as possible to be kept a separate detachment, and to be practised in their special war duties.

The cruisers to be detailed for this purpose should be the best of the "protected" class after those required to do duty as armoured cruisers had been apportioned. The duty of these ships in war will be to find and attack the enemy's commerce-destroyers, following them if necessary without regard to station limits. There will also be the merchant-vessels on the Admiralty list of subsidised ships. These ships can be armed at the first naval port they reach after being taken up; they are already running on the principal trade' routes, but it will be necessary to man them abroad, and, therefore crews mist be provicled at the base ports. Their principal duty will be the patrolling of the trade routes they are now employed on, and they should be encouraged to keep as many of the crew as possible belonging to the Naval Reserve. In addition to these two classes of sea-going vessels, there are others which will be useful in narrow waters such as the Channel, North Sea, parts of the Mediterranean, the entrance to the Red Sea, Singapore, the Straits of Sunda, inside the Barrier Reef, the West Indies, etc., where shipping passes on concentrated lines. For this purpose the four old broadside ironclads and the coast-defence ships might form bases for the sloops and gunboats not mentioned in the Admiralty return and also for destroyers and torpedo-boats. These ships when in reserve must be stationed at the nearest base ports to their war positions where crews can be obtained. When this is impossible the sloops and ships in commission for police duties would have to take their place as bases for destroyers. In many of these ports a depot ship would be required, and this might be the coastdefence ship allotted to that district, but in ôthers arrangem nts could be made for manning as suggested below for cruisers. The positions

1 The author is not quite accurate in his remarks about the cruiser squalron. The Cruiser or Training Squairon is still commanded by a commolore, not a rear. admiral, and is not attached to the Channel: as a vatter of fact, during the last few montlis it lias spent far more of its time in tle Yediterranean. Its future constitution scems to be still unsettled,-ED. 
selected must depend partly on the shelter such craft can obtain and on facilities for coaling, but by patrolling the narrow waters. in this way there would be certain fixed points formed where merchant-vessels could be sure of some protection. The enemy's commerce-destrojers are hardly likely to fight if they can avoid it, for the risk of being crippled would be too great even if they were successful, and if crippled their career would be practically over: We should therefore be able to employ even these weak vesse:s to some advantage.

It should be the duty of the admirals in charge of commerce-defence squadrons to arrange the best possible positions for the ships of whatever class they may have allotted to them. They should be kept informed of what ships they will have on the outbreak of war and where they are at any moment, whether in reserve or at sea, and orders should be drawn up and kept on board each ship, showing her position and duty on mobilisation.

\section{RESERVES.}

If the statement were made that the British Fleet could aford no reserves, it would of course be an exaggeration, but it is not far from the truth, if by the term Reserves is meant reinforcements to the battle fleets before they can go into action against the mobilised forces of the enemy. Either the actual fighting fleets in cummission must be strong enough to meet and defeat the enemy after he has mobilised, or we must be able to insure that the reinforcements shall have joined it beforehand. On general grounds it is clear that if we are to consider the enemy's coast our frontier, his reserve ships will have no distance to go after mobilising, while ours will have to steam from our base to join our fleet near his base. In the extra-European stations, with the exception of China, neither France nor Russia has any reserves, and we can therefore afford none except for commerce defence. In the European stations, though they have reserves, it would, in the case of the IIediterranean and Channel Squadrons, be impossible to ensure that we could reinforce our neets before the enemy could do so to his. It is quite feasible for secret orders to mobilise to be given to the French twenty-four hours before we know it. The distance from Toulon and Brest to Gibraltar is less than from our bases to the same place, and it would obviously be impossible for us to mobilise and arrive there in time to stop a junction. In order to prevent this, our two sq adrons if not already at Gibraltar would have to start immedia ely at full sperd, sending out cruisers towards the French ports to get touch of the enemy, so that each might force an action with its opponent at the earliest time. The Russian Squadron in the Nediterranean may be counted upon to be practically within touch of the French, but their "Black Sea fleet could hardly leave before war was cleclared, and a small division of the Mediterranean. 
Squadron would have to be told off to watch them, for we should have no time to commission and despatch ships from England or Malta for this purpose. Their Baltic Squadron would have to mobilise and so would be still in the Baltic, which would give us time to collect our coast and port-guard ships from the East and South coasts to oppose them, but if they had 24 hours' start in mobilising it is doubtful if we could meet them with any other ships before they had escaped to sea. Any ships, therefore, which we had to commission on the outbreak of war would only be of use either to assist in a blockade after it had been established or to reinforce the fighting fleets after they had fought an action. In China we have no base from which we could draw reserves of personnel nearer than Australia or Canada, the distances of which preclude the idea of reinforcements arriving in time to be of any service, and, therefore, on that station also we must depend entirely on commissioned ships to meet the enemy's battle flcets. So far as these fleets are concerned, we literally can not afford to keep any ships in reserve as reinforcements, that is, they cannot be brought into use until after the first developments have taken place. Therefore, the only reserves we can allow for the batlle-ships are those which are not required to meet the mobilised encmy in the first instance, that is, we can keep in reserve only those corresponding to such ships of the Dual Alliance as may be undergoing repairs which would prevent them being commissioned for at least a week after the outbreak of war.

It will obviously be unwise to keep any of the newer battle-ships and scouts anywhere except in co nmission, and it may be doubted whether the old broadside ships with muzzle-loading guns, which still figure in the list of effective battle-ships, would be of any value. "For criisers, reserves would be invaluable and a constant supply of them desirable, but here again we must keep our proper proportion of scouts in commission. Circumstances will be sure to occur, as at the late manceuvres, where scouts are obliged to fight, and whether sunk or disabled, the fleet they are attached to will be seriously hampered until they can be replaced.

When it comes to the defence of commerce, however, the position is different. Our large self-governing Colonies provide a certain proportion of personnel, and in the case of Austraita of ships also. On the first outbreak of war the enemy will detach certain ships to prey on our commerce, and the trade routes will want protection. It will inevitably take some time for the enemy to get his cruisers to the spots he selects, and a further time before we hear where these attacks are being made. In the meantime we may commission ships to deal with them: The attack on $c$ mmerce will be made partly by crutsers-some of them specially builı for the purpose-and partly by armed merchant-vessels: The enemy's 
difficulty will be his want of coaling stations, and of this we shall doubtless take full advanlage.

On the outbreak of war the cruisers in commission for commerce defence would at once proceed in search of any of the enemy's cruisers, which were known to be outside the harbour watched by our battle squadrons so as to bring them to action as soon as possible. The cruisers in reserve in England would commission and wait orders, their rôle being to chase any of the enemy's cruisers detached from his battle squadrons. Those in reserve on other stations would start immediately on commissioning along the principal trade routes connecting their base with other parts of the Empire so as to intercept any of the enemy's ships which hat escaped. They would report their arrival by telegraph at the first place they touched at, and receive information as to what enemy's ships were on that route and where they should be looked for. The cruisers already in commission on the stations in Group II. would at once proceed to get touch of the French vessels on those stations.

\section{MLANing the Reserves.}

If we keep cruisers at our colonial bases and arm merchant-ships there, we must be prepared to man them, and the only places out of England where we can do this are our large self-governing Colonies. We have, it is true, a training-ship for ordinary seamen in the Mediterranean, whicli would necessarily have to lay up in war-time. Her crew might, with the depot-ships, furnish.crews for two cruisers, provided that their crews were not required to fill vacancies in the fleet: But in Canada, Australia, New Zealand, and doubtless later on in Suth Africa, there are trained men ready and willing to be einployed in the naval defence of the Empire, but so far, to a large extent, unorganised for this purpose. With propar organisation we ought to be able to keep whatever ships we want at these bases ready for mobilisation. This, however, involves the nucleus of a highly-trained force in sufficient number to fill the principal ratings in the ships to be conmissioned. Th"se must be provided from men and officers in fuil pay and training. The remiader of the crews would be provided by the colony from their naval forces. For this purpose it would be necessary to establish for each of these stations its own training schools, in addition to a depot-ship, and to mobilise periodically for training. The bases in such Colonies might be organised on the lines of our home naval ports. A depott-ship or barracks for men of all ratings, gunnery, torpado, and signalling schools, and training arrangements for scamen and stokers. - These ports should have a senior naval officer in charge of all the naval arrangements, there should be a sufficient staff of officers attached to the training schools, and ratings on the stations 
should requalify there. Officers and men of the Royal Naval Reserve should also be allowed to go through their training on board these ships, and such men of the Fleet Reserve who might be there. The schools themselves might with advantage be the ships to be commissioned there in war-time, so that there would be a nucleus of highly-trained officers and men always ready and familiar with the ships they would have to serve in. The local naval force should be encouraged in every way, both officers and men, and made to feel that they had a definite part allotted to them in the naval defence of the Empire. This force on ordinary occasions is separated from the Navy and is under their own rules, but they should be required to amalgamaie for periodical training with the Navy, under naval regulations, in the ships they would actually serve in during a war. With tact on the part of the officers of the schools there should be no difficulty about this, but it should be arranged that on mobilisation this force should be directly under the command of the admiral on the station and entirely independent of the Colonial Government. 'The Navy must be dircetly under the Admiralty in war-time. There must be no divided responsibility or command, and there should be no difficulty about this if the true functions of the Nayjare recogniised, namely, io keep the scas clear of the enemy, and not to defend the ports or coasts, and that for this purpose it will often be necessary to detach ships long distances from their base ports-sometimes to other stations.

The great divisions of the Empire beyond the sea have already recognised that the Navy is Imperial $\mathrm{ky}$ providing certain sums of money for war-ships. They have already sent-men freely to South Africa, China, and the Soudan, and there can be no doubt but that thes would be prepared to fall in with some such scheme of mobilisation for the Nay which they could appreciate and understand, and that they would not hamper the. Admiralty with restrictions as to where ships and men sliould or should not be cmployed, provided that the system to be adopted were made clear to them. Locil conditions must, howerer, be taken into consideration. Iocal rates of pay, local ideas of discipline, local ideas of dress even, should be given due thought where such exist, and must not be allowed to precint the thorough amalgamation of the Service into one efficient whole. Strict discipline is necessarily required in the Nay; but in war-time a good deal may be omitted in petty detail which would not be permissible in peace, and on mobilisation for drill, war, rather than peace, conditions should be observed.

On the East Indian Station arrangements could also be made to man commerce-defence ships, though, at present, the value of the Indian Marine Service is hardly taken into account. 'I'he officers and men of this Service are used to working together and are under cliscipline, but they are not sufficiently trained as a fighting force, nor would it be 
possible to mix the men of that Service with our own. At the same time, with a certain leavening of petty officers from the Service, there seems to be no reason why an efficient force for war purposes should not be developed. Such petty officers would necessarily have to serve with the men in peace-time so as to learn their language and understand their character; but with this and a better war training for that Service there seems to be no reason why a force fit to take over commerce-defence ships in war-time should not be organised. It might be arranged that they should maintain and man two or three efficient cruisers in peace under the Indian Government, instead of their present obsolete vessels, so that there might be a constant training going on in their own Service; then on the outbreak of war they could at once pass into the Navy with other reserves.

\section{MIOBILISATION.}

The object of mobilisation is to put the Navy on a war footing by commissioning all vessels which can be of use, and the organisation for this purpose should be directed towards getting these vessels commissioned and ready for action as quickly as possible with the men best suited to them. The latter principle is sometimes overlooked, and it is then assumed that officers and men on the active list should be mixed with the various reserves to such an extent that a sort of uniformity may be arrived at. It appears doubtful if this is sound policy. The active list is composed of those who are accustomed to the newest ships and guns, the reserves to an older style of both. These newest ships will be the first to come into action, the older type being merely a reinforcement after the others have borne the first shock. It would, therefore, secm better to put into the first line those who can best do justice to the ships, and into the second the reserves. From the foregoing pages it will have been gathered that these are the lines here proposed. 'The battle fleets will already be in commission, also certain of the ships for the protection of commerce. There will remain some motern cruisers, destroyers, and torpedo-boats, also some old battle-ships and cruisers, as well as some armed merchantmen and the fleet auxiliaries, such at coal, hospital, stores, and repairing ships. The former group, i.c., modern cruisers (at least those of them which are to be employed for fleet work), the destrojers and torpedo-boats, should be manned from the active list ; the commercedefence cruisers at our bases in the Colonies by the Coloninl Navies, depotships and training schools; the older battle-ships by the officers on th: retired list and men of the Flect Reserve; and the merchant cruisers and auxiliaries by the Naval Reserve. In the cilse of all but the auxiliaries, the captains and gunnery officers should be taken from the active list, as also should the captains of guns and to some extent the signal staff. The rescrve battle-ships would then be manned by both officers 
and men who, while in the Service, had been used to this class of ship. They would soon feel at home in them and should, by the time they had joined the squadrons to which they were to be attached, be able to take up their duties efficiently. Similarly with the merchant cruisers and auxiliaries, their crews would have been used to the class of ship they would be employed in and so would the sooner get into the work, but an exception. would have to be made in the case of ships employed to "mother" destroyers and torpedo-boats attached to the battle fleets, where at least the majority of the crews should be from the active list. Of course it would be impossible in practice to make quite such hard and fast lines as these; there will, for instance, be certain officers and men. of the Naval Reserve serving in the fleet when war breaks out, and these cannot be exchanged and sent to other ships; but if these general principles were laid down, those liable to be called out in war-time would know what to expect and would fecl that the work they would have to do would be such as they were familiar with. There are, however, on all these auxiliary lists a certain number of both officers and men who are somewhat too old to take the positions here assigned to them. 'These could be usefully employed in the very responsible duties of coaling, obtaining and sifting information, and relieving some of those at the Admiralty, in depott-ships, and barracks.

It would conduce to efficiency if the officers on these reserve lists could be kept informed of the ships they would have to join on mobilisation. This would involve a certain amount of correspondence in peacetime, for necessarily there would be alterations from time to time; but if an officer knew what ship he would be called upon to join, he would in most cases take some trouble to make himself acquainted with her structure and armament; or if he would have to undertake other duties, he would ascertain how these dutics could best be carried out. But in such cases it would be necessary to arrange that the officers seeking the information were given facilities to acquire it. The watch and station bills for reserve ships might be already made up for them, with the cxception of the actual names of the men. This could be done from the watch bills of their last commission or from those of similiar,ships. Small plans of the ships, showing pipes and fittings, others giving plans of the armour and details of armament might be prepared and copies printed, extracts from the ship's book might also be useful, and generally any information which would enable the officers to know their ships. Such details would hardly be required for ships to be commissioned from the active list or in the Colonies, for in the former case the officers may be presumed to know, or to be in the way of casily obtaining the necessary information, and in the latter it is assumed that they will have mobilised in their ships during peace. For such ships as 
are to be manned to a large extent by reserves, such details would be very valuable, as allowing more time to be given on mobilisation to preparation for battle.

With regard to stores for ships not in commission, it is an open question whether it would not be advisable to adopt the German system and to put every possible store required by each ship in one place. This would save time, though it might waste space. The arguments in favour of this system are certainly strong, and it seems worth a trial. Difficulties in connection with storekeeping accounts are not insuperable, and in all probability if our dockyards were organised more on a military as opposed to a civilian basis (as in Germany) it would be adopted. On the other hand, our present system works well, and it will naturally be asked why we should alter it. There could be no objection, however, to giving the other system a trial, and with a view to this it might be adopted in one of the naval ports as an experiment.

All ships in reserve should have the gear removed which would be thrown overboard before an action, with the exception of boats and certain cabin and lower deck fittings. There can be no object in our old masted battle-ships taking a lot of spars and sails to sea with them or for the older mastless ships to take more woodwork to sea than can possibly be helped. They are not being manned for a three years' commission in peace-time, but for war, and the less they have that is not absolutely necessary the better. The weight of these stores could be far better utilised in additional coal and ammunition.

When the orders to mobilise are issued, the crews of such vessels as are to be manned by reserves cannot all arrive at the same time at the dockyard, but there should be no necessity to wait for this to hoist the pendant; valuable time for getting stores on board would be lost by this means. If all the stores belonging to the ship were in one place and the ships were moored as near it as possible, working parties could be organised as soon as the first few men arrived."

\section{Summary.}

The arguments advanced and the conclusions arrived at above may now be summarised:-

1. It is necessary for our existence as an Empire that we should have the command of the sea, and the coalition most likely to challenge this would be the Dual Alliance. We must, therefore; be prepared to defeat or contain their battle squadrons and protect our commerce. "In order to properly perform these duties, the Navy must be free to adopt offensive strategy and to send its ships and men to the frontier, i.e., the enemy's coast, without being hampered 
by portor coast defence. A dividing line between naval and military command is required and the 3 -mile limit suggested.

2. The exigencies of commerce defence may require ships to proceed to any point independent of peace stations. Scouts and commerce-defence ships have essentially different duties, which cannot be combined, and the adimirals in command of battle fleets should have a frec hand. It is, therefore, suggested that the defence of trade routes should be entrusted to an admiral specialiy appointed.

3. The battle fleets in all waters require to be kept at full war strength, including the proper proportion of scouts. Commerce-defence ships can be partly in reserve in various ports at home and in our self-governing Colonies. At these bases there should be depôt-ships and training-schools.

4. The port and coastguard ships are here counted as a battle squadron and require a proper proportion of scouts.

5. Torpedo-boat destroyers should be attached to the base ports of stations, some part being always in commission. They should not accompany the fleet to sea, but should be prepared to join it or act independently as required. Torpedoboats should be attached to certain parts of the coast, not to defend it, but with a view of making raids on any enemy's ship in the neighbourhood. Flect auxiliaries to be kept in commission where-they can be usefully employed.

6. Fleet cruisers in reserve, destroyers, and torpedo-boats to be manned on mobilisation by depôt-ships, barracks, and schools (active list), commerce-defence ships, old ironclads and old cruisers, by officers on retired list and fleet reserve in England; commerce-defence ships abroad by colonial navies; armed merchant-ships and fleet auxiliaries by: Naval Reserve. Each ship manned to have captain, gunnery officer, and certain ratings from active list.

7. Officers in various reserves should be kept informed of the ships and ports they will have to join on mobilisation, and be afforded facilities for obtaining information as to details of these ships and duties. It is suggested that the German system of stores for mobilisation should be tried in one of the dockjards, and that all spare gear not required for battle should be eliminated from ships in reserve.

\section{Notes oN the Tables.}

A distribution of the flcet on the foregoing basis must depend principally on the position and readiness for war of the French and 
Russian ships, details which only the Admiralty can know with any accuracy. In attempting such a distribution, therefore, it must be taken as merely an illustration of the ideas expressed above and as liable to considerable modification were fullèr information on these points obtainable.

- It is assumed that the French and Russian ships are distributed as shown in Tables II. and III., and our own fleet is apportioned accordingly. Victory in the end must be decided by the battle squadrons, and it is, therefore, imperative to provide first for them. This implies a considerable reduction of our squadrons on extra-European stations, and a general concentration of the fleet. In view of the increase of the French and Russian Navies, this appears to be necessary.

TABLE I.

Flects of Great Britain. France, nul Mussia (Admiralty Return of Ships built, 2sth Wurch, 1901).

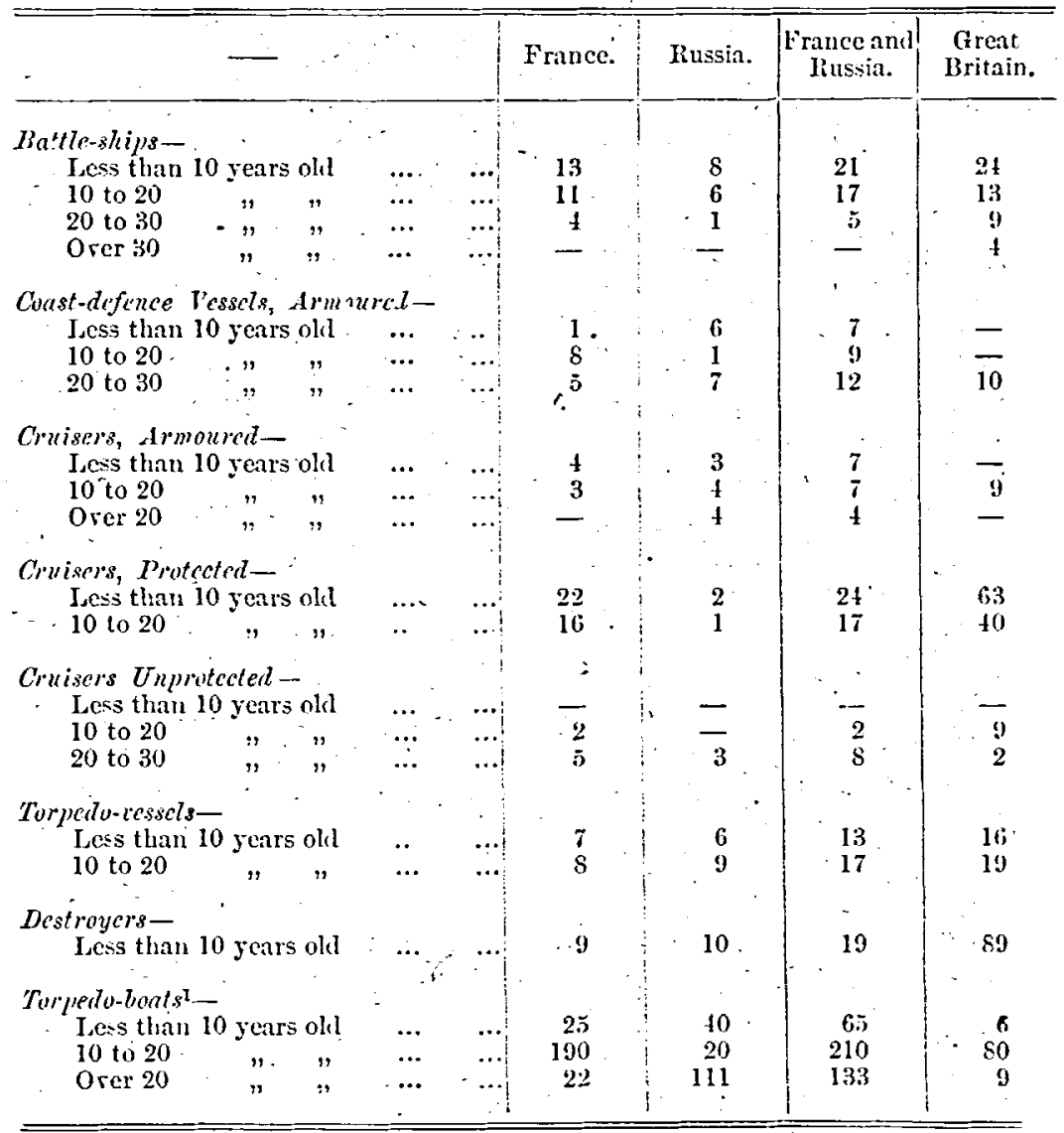

1 Distribution according to age approximad. 
TABLE IJ.

Distrilution of Battle Flccts.

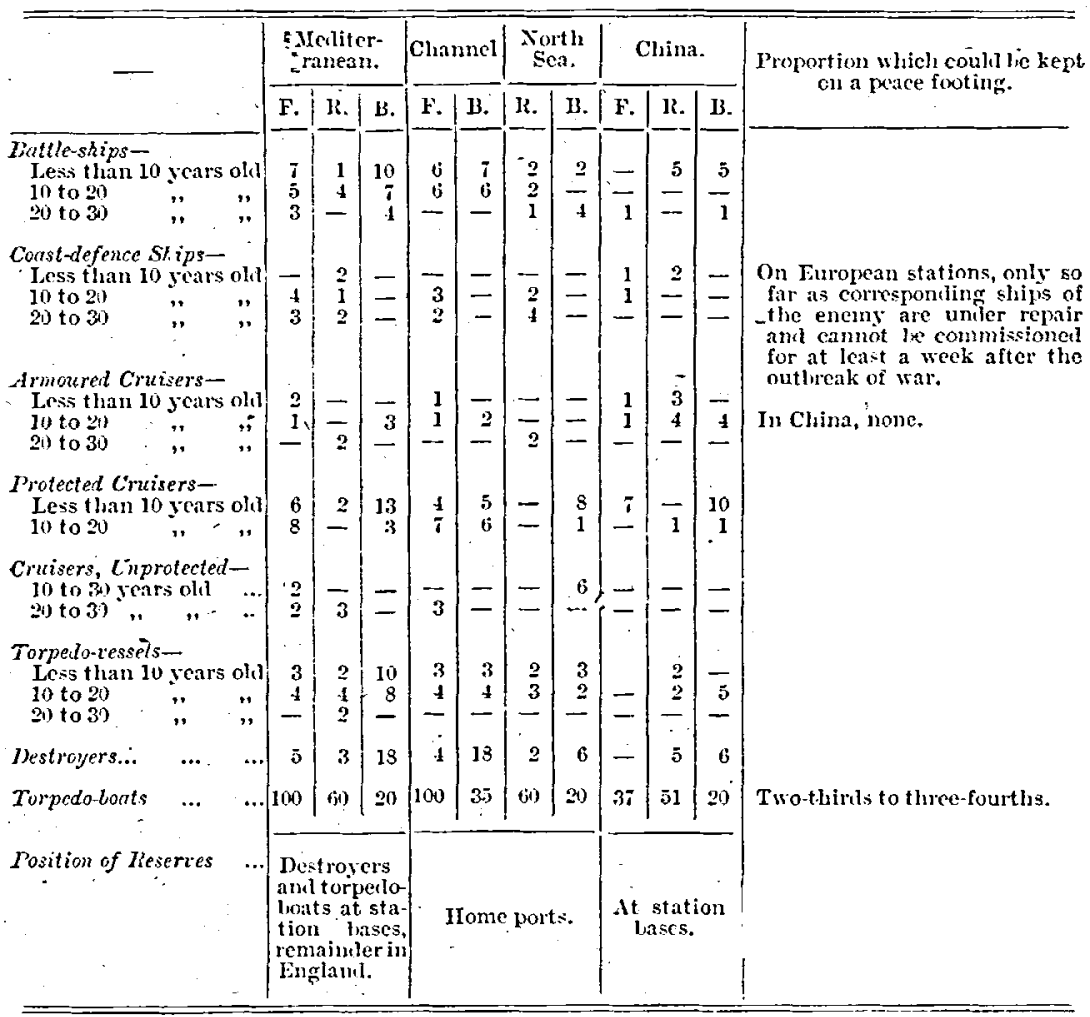


TABLE. III.

Distribution of Commerce-Dofence Ships (British).

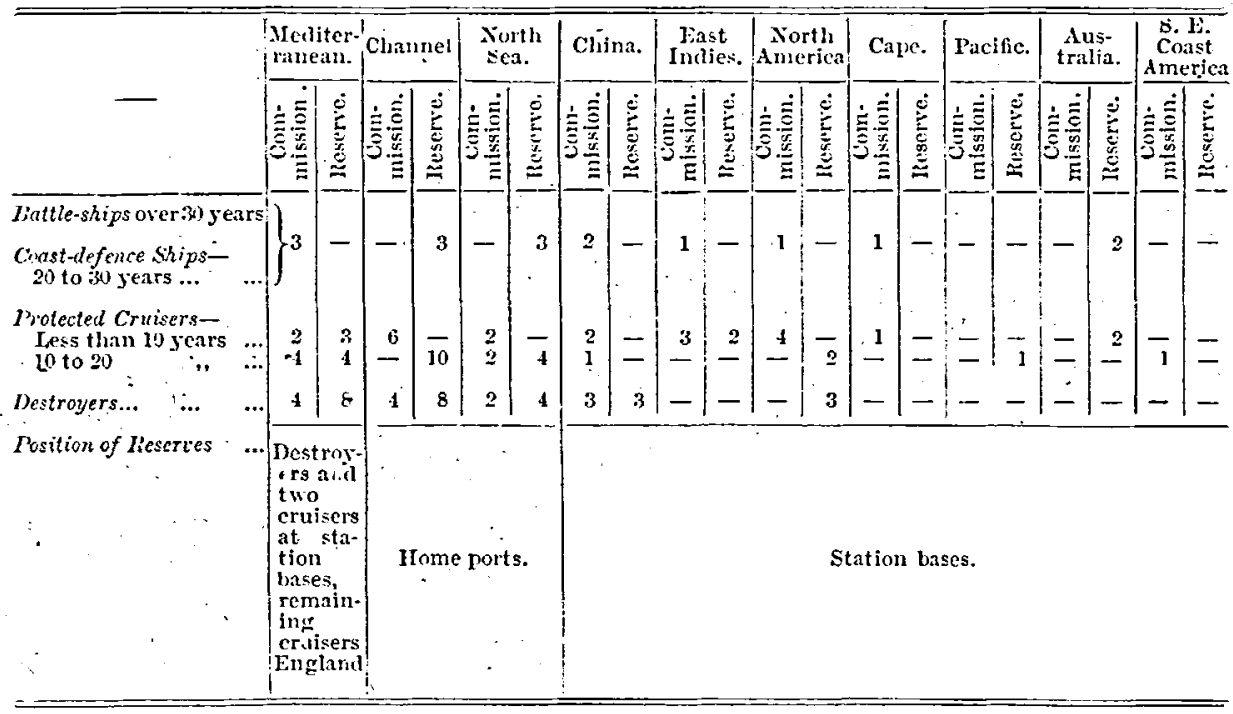

Note.-It is assumed that tie French have in the East Indies 2 and in Forth America 3 protected cruisers, all less than In years old, and on the latter stationl 1 other from 10 to 20 years oll. The sloops and gun lonts will be distributed as required during yeace for folice dities, some of them moving to ot ber staticns for war, $e$ y, those on West Coast of Africa to Mediterranean, those on East Coast to Alen and Zanzibar, those on Sonth-East Coast of America to West Indies, while those in reserve in England would le distributed ronnd the coasts. Thie armed inerchant-vessels would patrol their own trade routes, manning at the first naval base they reached. 